\title{
Interprofessional relationships of a patient assistance team in critical care
}

\author{
Relações interprofissionais de uma equipe de assistência ao paciente em cuidados críticos \\ Relaciones interprofesionales de un equipo de asistencia al paciente en cuidados críticos
}

Letícia Gabriela de Almeida Noce'
ORCID: 0000-0003-2156-6938

Taynara Souza de Oliveira" ORCID: 0000-0001-8281-0151

Larissa Cândida Melo" ORCID: 0000-0001-6862-300X

Kerollyn Fernandes Bernardes Silva" ORCID: 0000-0002-2282-7063

Bibiane Dias Miranda Parreira" ORCID: 0000-0001-7369-5745

Bethania Ferreira Goulart" ORCID: 0000-0003-2855-6767

'Universidade Federal de Uberlândia. Uberlândia, Minas Gerais, Brazil. "Universidade Federal do Triângulo Mineiro. Uberaba, Minas Gerais, Brazil.

How to cite this article: Noce LGA, Oliveira TS, Melo LC, Silva KFB, Parreira BDM, Goulart BF. Interprofessional relationships of a patient assistance team in critical care. Rev Bras Enferm. 2020;73(4):e20190420. doi: http://dx.doi.org/10.1590/0034-7167-2019-0420

Corresponding author: Bethania Ferreira Goulart E-mail: bethaniagoulart@yahoo.com.br

EDITOR IN CHIEF: Antonio José de Almeida Filho ASSOCIATE EDITOR: Hugo Fernandes

Submission: 08-07-2019 Approval: 11-16-2019

\begin{abstract}
Objectives: to identify perceptions of teamwork according to the professionals of an Adult Intensive Care Unit. Methods: descriptive research with qualitative approach. The methodological framework was thematic content analysis. The theoretical framework of the work process was used to guide the interpretation of the data. Data collection: A semi-structured interview was conducted with 38 professionals in a public teaching hospital in the state of Minas Gerais. Results: three thematic categories emerged from the interviews: Work Organization, which is related to work performed through tasks/routines, with or without coordinated actions; Non-material Work Instruments, which reveal that teamwork is based on communication/collaboration; Insufficient Material Resources, which indicate that lack of material creates conflicts between professionals. Conclusions: Teamwork requires effective communication and collaboration, integrated work and appropriate professional training. On the other hand, fragmentation and rigidity at work, poor collaboration/communication and lack of material make teamwork difficult. We emphasize the need to revise the curriculum of health courses, with a view to including and/or improving discussions about teamwork in order to train professionals for a more integrated and perhaps even sympathetic health practice.

Descriptors: Patient Care Team; Cooperative Behavior; Interprofessional Relations; Critical Care; Hospital.
\end{abstract}

\section{RESUMO}

Objetivos: identificar as percepções do trabalho em equipe segundo os profissionais de uma Unidade de Terapia Intensiva Adulto. Métodos: pesquisa descritiva, com abordagem qualitativa. Utilizou-se como orientação metodológica a análise de conteúdo, modalidade temática. Recorreuse ao referencial teórico de processo de trabalho para guiar a interpretação dos dados. Coleta de dados: Realizada entrevista semiestruturada, com 38 profissionais em hospital público de ensino, localizado no interior de Minas Gerais. Resultados: das entrevistas, emergiram três categorias temáticas: Organização do trabalho, que evidencia trabalho realizado por meio de tarefas/rotinas, havendo ou não ações articuladas; Instrumentos não materiais do trabalho, os quais revelam que o trabalho em equipe fundamenta-se na comunicação/colaboração; Recursos materiais insuficientes, que indicam que falta de material gera conflitos entre profissionais. Conclusões: $O$ trabalho em equipe requer comunicação e colaboração efetivas, trabalho integrado e formação profissional adequada. Por outro lado, fragmentação e rigidez no trabalho, pouca colaboração/comunicação e falta de material dificultam a realização do trabalho em equipe. Aposta-se na necessidade de revisão curricular dos cursos da saúde com vistas à inserção e/ou aprimoramento das discussões sobre trabalho em equipe a fim de instrumentalizar os profissionais para um fazer em saúde mais articulado e quem sabe até solidário.

Descritores: Equipe de Assistência ao Paciente; Comportamento Cooperativo; Relações Interprofissionais; Cuidados Críticos; Hospitais.

\section{RESUMEN}

Objetivos: identificar las percepciones del trabajo en equipo según los profesionales de una Unidad de Cuidados Intensivos para Adultos. Métodos: se trata de una investigación descriptiva, con enfoque cualitativo. Se utilizó como guía metodológica el análisis de contenido y la modalidad temática y el marco teórico del proceso de trabajo para guiar la interpretación de los datos. La recolección de los datos se llevó a cabo mediante entrevista semiestructurada con 38 profesionales en un hospital-escuela público, ubicado en el interior de Minas Gerais. Resultados: de las entrevistas surgieron tres categorías temáticas: Organización del trabajo, que evidencia la labor realizada con tareas/rutinas, habiendo o no acciones coordinadas; Instrumentos no materiales de trabajo, que demuestran que el trabajo en equipo está fundamentado en la comunicación/ colaboración; Recursos materiales insuficientes, que provocan conflictos entre los profesionales. Conclusiones: el trabajo en equipo requiere una comunicación y una colaboración eficaces, una labor integradora y una formación profesional adecuada. Por otro lado, la fragmentación y rigidez del trabajo, la escasa colaboración/comunicación y la falta de materiales dificultan el trabajo en equipo. Es necesario una revisión curricular de los cursos de salud con miras a la inserción y/o mejora de los debates sobre el trabajo en equipo, con el fin de instrumentar a los profesionales de la salud para una práctica sanitaria mejor coordinada y quizás, incluso, solidaria.

Descriptores: Equipo de Atención al Paciente; Comportamiento Cooperativo; Relaciones Interprofesionales; Cuidados Críticos; Hospitales. 


\section{INTRODUCTION}

Although collective and integrated work represents a potent strategy for the health area, some services are still strongly influenced by professional training based on the clinical model of care and organization based on the functional method. These aspects are opposed to collective and integrated work, which compromises teamwork ${ }^{(1)}$. In this perspective, training as mentioned does not enable professionals to value and deal with the relational dimension of teamwork ${ }^{(2)}$.

The organization chart of the services can be a factor that creates obstacles and limitations in the communication between the different professionals, which hinders collective and coordinated actions in health care settings $s^{(3)}$. The organization of work based on professional dichotomy leads to fragmented care $^{(2)}$ and does not favor integration between different knowledges, nor does it enable articulation between health professionals and health practices.

However, it is worth noting that collaborative teamwork is of fundamental importance for the quality of health care, safety and satisfaction of both patients and professionals ${ }^{(4)}$. For this, communication and collaboration between the agents involved in care is crucial for the its effectiveness ${ }^{(5)}$. Teamwork is about connection between professional assignments, tasks or activities. In this sense, to form a team, there must be dialogue, acknowledgement and appreciation of the other, cooperative attitudes, consensus, horizontal relationships and common goals ${ }^{(6)}$.

Teamwork is seen as a possibility for collective and integrated work, so that care can be more than a set of disconnected procedures and actions focused on pathologies. From this perspective, it is understood that this is consistent with the Intensive Care Unit (ICU), where the demands and needs of patients and professionals, the technological resources, the physical space and the environment of the sector require satisfactory professional interaction to enable comprehensive care.

It is pertinent to highlight that closed critical units, such as the Adult ICU, usually make the professionals spend a longer time together. This may generate greater physical proximity, but it does not ensure a coordinated teamwork. It is also highlighted that the ICU is a sector in which professionals deal with critical illness, suffering of family members and a thin line between life and death, which can generate stress and overload, affecting the relationships between team members. Professionals know how to provide care using modern and sophisticated equipment; however, they may have difficulty interacting with others, sharing therapeutic projects and acting in a coordinated manner. Given all the above, the question is: how do the professionals of the Adult ICU think and how do they experience teamwork in that context?

Investigating the perceptions of professionals on teamwork in the adult ICU can contribute to the design and implementation of actions that enable its effective implementation. Moreover, it is observed that these issues have not yet been investigated in this specific scenario.

\section{OBJECTIVES}

This investigation aims to identify perceptions of teamwork according to the professionals of an Adult Intensive Care Unit.

\section{METHOD}

\section{Ethical aspects}

This research is part of a larger project titled "Teamwork in Hospital Units: Facilitating Factors and Difficulties", which was approved by the Research Ethics Committee on involving human beings (CEP) of the Federal University of Triângulo Mineiro (UFTM), via Plataforma Brazil, under CAAE: 63572317.2.0000.5154, and protocol number $2,073,096$. The research participants signed the Informed Consent Form (ICF) and confidentiality and privacy were respected.

\section{Type of study}

Teamwork is a complex modality of work, as it involves many different aspects. In this study, the purpose was to identify the perceptions of teamwork according to the professionals of an Adult ICU. For this, a descriptive study with a qualitative approach was conducted. This design enables the understanding of meanings, beliefs and values about a given situation or phenomenon ${ }^{(7)}$.

\section{Study setting}

The study was conducted in an adult ICU of a tertiary public teaching hospital. The hospital has 302 beds, of which ten are for the adult ICU, it is located in a city in the state of Minas Gerais and it is a reference in high tech care.

\section{Data source}

Professionals from the health team of the adult ICU were interviewed. The participants were those who met the inclusion criteria, which consisted of working in the unit for at least one year. Those who were away from work at the time of data collection, those who refused to participate and those not located after three attempts to schedule the interview were excluded.

\section{Data collection and organization}

Data collection occurred from August to November 2017. Data were collected through a semi-structured interview guided by a script, which was subjected to face and content validation by three experts on the subject and/or on the research methodology adopted. The script was elaborated by the researchers themselves and was divided into two parts: the first was related to the sociodemographic and professional data of the participants; and the second part was composed of guiding questions to investigate the professionals' perspective on how the work was performed and their perceptions about teamwork.

The interviews were conducted by the researchers, who received training for this task, and occurred face-to-face. The audio was recorded in digital media. They had an average duration of seven minutes, and occurred in a previously scheduled day and place, in common agreement between the participants, the professionals responsible for the service and the researchers. Interviews were held in a private environment in the hospital itself. 
Participants were named E1, E2, E3, and so on, up to E38. The letter $E$ is used to represent the interview and the number represents its sequential order. It is worth noting that there was no need to identify and distinguish professional categories, as the study was interested in the team as a whole.

\section{Data analysis}

The interviews were fully transcribed by the researchers. The methodological framework of thematic content analysis was used for data analysis. It is composed of three stages. The first stage, identified as pre-analysis, consisted of intense and exhaustive reading of the material, aimed at apprehending the whole data and the particularities of the set. The second stage is the exploration of the material, identifying categories and grouping units of context. In the last stage, interpretative synthesis, the sections were grouped according to the themes that emerged and were organized into thematic units ${ }^{(7)}$. Data analysis was performed approximating the Work Process theoretical framework ${ }^{(8)}$ and the study object.

\section{RESULTS}

At the time of data collection, the Adult ICU had 66 health professionals, of which 31 were nursing technicians, 17 were physicians, nine were nurses and nine were physical therapists.

Of the 66 professionals, 38 participated, of which 18 were nursing technicians (47.4\%), ten were doctors (26.3\%), six were nurses (15.8\%) and four were physical therapists (10.5\%).

A total of 28 professionals did not participate, as 15 were not found after three attempts to schedule the interview, five had less than one year of work in the Adult ICU, five were away from work at the time of data collection and three refused to participate.

Among the 38 participants, 22 (57.9\%) were female and 16 (42.1\%) were male. Participants were between 26 and 65 years, with a mean age of 38 years. Regarding training, 26 (68.4\%) professionals completed higher education, four (10.5\%) had an incomplete higher education and eight (21.1\%) completed high school. It is worth noting that 22 professionals (57.9\%) had some type of complementary education, and among them, 18 (81.8\%) had a specialization degree, three (13.7\%) had a master's degree and one ( $4.5 \%)$ had a doctorate degree. The mean time of training was 14 years, and time working in the adult ICU ranged from one to 24 years, with a mean of seven years.

Based on the interviews, three thematic categories emerged: Work Organization, Non-material Work Instruments and Insufficient Material Resources. The thematic categories revealed the professionals' perceptions about the work performed and teamwork, and highlighted aspects that help or hinder teamwork in the adult ICU.

In the thematic category Work Organization, respondents reported that work is performed through tasks and routines established according to specific professional category, which reinforces the division of labor, and there may or may not be coordination between practices and actions. They reported that each professional is an agent of the work process and has their own pace and way of doing the work. This thematic category encompasses aspects that hinder or facilitate teamwork, from the perspective of the participants.
According to the professional category, doing fragmented work can make the work activities repetitive and mechanical. The rigidity in the work routine is also indicated as a factor that hinders its accomplishment. These issues were identified by the participants as difficulties of teamwork, as shown in the following statements:

Working time is very long [...] for me some things are very rigid [...]. I thought like this: we have predefined schedules. The patient does not stop [...] we have other things to do, for example: we have to send material to the center by four p.m. But what if there is an emergency, something like that? We can't do that. But it's a complicated issue, right?! (E2)

[...] look, it's hectic [...]. The unit is very busy, mainly because of the schedules [...] it's busier in the morning because there are exams, there are evaluations with surgeons, with residents with the intensive care physician. So, it's very crowded sometimes. No! Always [...] it's hectic. Sometimes you will start the bath, and then you have to stop to take the anamnesis with the resident. When it is not the resident, it's the surgeons, with the residents of their respective [...] specialties [...]. So, we do the job with a lot of difficulties. Because everything is in the morning. Most patient care is in the morning, from anamnesis to exams. (E20)

Ah [...] it's virtually a robotic work. We arrive and we already know what we have to do, check vital signs, medication, bathing, changing beds, daily things [...] each one has their own pace and way of doing the work. Some people are slower, others are more agile. So you have to know how to work with each one, and at their own pace, even if it's hard (laughs). (E32)

Regarding the obstacles to teamwork, the Work Organization category shows that work overload due to understaffing issues and lack of time to discuss clinical cases and hold meetings are identified as a limitation for teamwork, as exemplified in the following statements:

[...] sometimes, there's overload. Sometimes there's just one nurse, just one physical therapist, and sometimes we get overwhelmed and can't help a lot. (E19)

Another factor [difficulty] is the lack of time to interact more; our workload has a lot of assistance, we could take this workload and split it between meetings, case studies, this would be easier. (E33)

Lack of time, sometimes our colleagues are overloaded and cannot help, because they are exactly like ourselves... full of work, then it's like... '-hold on, I'll be there in a minute'! This is all due to work overload. (E35)

However, despite the different difficulties identified by the participants, some interviewees revealed that, even with the division of labor, there is also some coordination between professionals and their knowledge and actions, an aspect that facilitates teamwork:

[...] I believe that [...] trying to understand each other's function, without overstepping boundaries [...] without taking the activities that are part of the other person's function, and so on. (E15)

We usually follow the routine. We arrive, check vital signs, see the patients, do the aspiration when there is no physical therapist, 
change the patients' position if needed, and continue with the service. Everybody together. (E26)

Every day is the same, we arrive and begin, I think the dynamics are good! The staff is in sync, it's a good team. (E35)

Another aspect pointed in this thematic category as a facilitating factor for teamwork is that a reduced number of patients for care contributes to teamwork in the adult ICU, as shown in the following statement:

[...] I think that the number of patients helps, here in the ICU there are two patients for each technician, then I think we can help each other more [...] in the ICU, because it is a sector that has legislation, we can help each other, as we only have two patients. Because of this I think everyone can help each other [...]. It's two patients and that's it, there's never more. (E19)

The category Non-material Work Instruments encompasses one of the elements of the work process and reveals that, according to professionals, proper teamwork is based on interpersonal relationships with proper communication, collaboration, cooperation, unity, respect and mutual help. This category included facilitating factors and difficulties of teamwork in the Adult ICU, according to the participants.

According to the reports, teamwork requires collective and coordinated work aimed at expanding assistance and promoting comprehensive care. This can be made possible by non-material instruments. Thus, participants identified as facilitating factors for teamwork: communication, collaboration, respect for each other and mutual help. This can be seen in the following statements:

[...] being heard [...] and everyone being able to speak their mind [...]. Communication between professionals [...] a doctor who can listen to the nurse, to the nursing technician, on what they think, what they saw, they are often our eyes and they can draw attention to something that was not noticed, then you can change it, sometimes even in relation to the diagnosis, a nursing technician might have noticed something that you didn't. Então, essa relação de respeito, de comunicação adequada talvez seja o grande fator, o de maior importância [...] se isso não acontecer quem sai prejudicado é o paciente. (E21)

[...] teamwork in health [...] when you are performing a procedure, if you have difficulty, there is a colleague who is [...] willing to go there and help you without being asked. (E24)

The following statement indicates that the professional may even know the actions that must be performed, but the collective perspective represents a crucial factor for the development of teamwork and the effectiveness of care:

[...] we had an emergency [...] the patient had a hypertensive pneumothorax [...] the patient [...] stopped in front of us, we would have to do a chest drain without anything, if you wait to do this the patient dies in front of you, and where's the scalpel? I cut him with the scalpel without anesthesia or anything, opened the guy's chest and put the drain there, that's what saved the patient, but the nurses were by our side. Without them I can't do anything. They are important, they are key figures. (E5)
From the perspective of non-material work instruments, adequate knowledge and training are tools that facilitate teamwork, as exemplified by the following statements:

[...] it is necessary, mainly when it comes to professional training, which is the case here, as it is a teaching hospital, that professionals learn that they depend on other professionals to perform their work [...] if the professional understands that the health team is interdependent since the beginning of their education [...] maybe if we begin addressing this issue since their training [...] then we can move towards improving even more this issue of teamwork [...]. (E6)

The dynamics, because we have a lot of dynamics, and also some lectures, make it easier for us to get closer [...] to be closer to each other, to know more about each other, and also to find consensus [...]. (E38)

When these non-material instruments are not properly experienced, enmeshed in individualism, fragmentation, lack of collaboration, inappropriate communication, and difficulties in consensus and standardization of conduct, they become a hindering factor that undermines teamwork, as it can be observed in the statements:

Individualism [...] the personality of each one [...] sometimes, the person tries to impose their beliefs and their pace [...] when we are impatient, we can be rude with someone else, or we don't understand what the person is telling us [...]. Because when there is a lot of individualism in a sector, especially here, that it is closed [closed sector], our daily life and our work becomes difficult [...]. (E13)

[...] lack of communication [...] this issue with this barriers that really exist [...] there is a lot of lack of communication [...] when we began, we could not [...] go straight to the doctor and report a pupil change [...]/think that's missing [...] because sometimes the technician knows how to identify certain signs and symptoms that the patient is experiencing during their duty and if they comes to talk to the doctor they are ignored, you know? [...] unfortunately, I think it's like this! I think there is still a barrier, I think they believe that the technician doesn't know anything [...] how can I explain... that they know nothing but changing a diaper, understand? And we have knowledge too, notonly technical knowledge, we have scientific knowledge. (E14)

The category Insufficient material resources only include factors that hinder teamwork. It reveals that lack of material compromises the performance of care, creates conflicts between professionals and undermines teamwork. The reports are directly related to the material instruments of the work process, as shown in the statements:

[...] sometimes, it is difficult here because there's issues of material [...] because there is no material. Then it's hard to work. You have staff but there is no way to do the job. Then, it comes to a halt [...] it's difficult, but not because of the staff, because of the structure. (E11)

[...] the support from the hospitality sector, which would be the bedclothes, makes it harder. [...] Then, the residents position the patient, insert a central line, a radial artery access for the blood gas analysis [...]. Then we have no bedclothes. Then we have a dirty bedding. What do we do? Then another team comes "ah, it's dirty, why didn't you change it?". Sometimes it's a small drop of blood and it causes a fuss. (E20) 


\section{DISCUSSION}

Based on the interviews, some elements of the work process emerged in the reports, such as the purpose, the agents and the material and non-material instruments ${ }^{(8)}$.

The category Work organization shows that the way work is thought and performed, its organization and the quantity of agents are factors that affect the assistance provided and the purpose of the work process.

When work organization occurs through the delimitation of tasks and routines, is divided according to professional category, and is based on a logic of fragmentation and rigidity, it represents a difficulty for teamwork in the adult ICU and it may compromise the purpose of the work process, which is comprehensive care.

These results are supported by the literature, which reveals the existence of teams that develop their work in a fragmented and individualized manner, which impairs their work. This may be a consequence of the professional hierarchy that still exists in daily life ${ }^{(9-10)}$. It is pertinent to emphasize that fragmentation and low coordination may be due to the lack of formal incentive to promote and stimulate interaction between professionals ${ }^{(9)}$.

Work overload and understaffing were perceived by the interviewees as difficulties for teamwork. These issues also affect the collaboration between agents, which can influence the purpose of the work process and impair the care provided.

The results are consistent with the literature, which shows that, even though many professionals emphasize the importance of actions related to teamwork, these are often not discussed due to work overload and lack of time. These issues restrict teamwork and generate professional actions that are not discussed nor planned in an inter-professional manner ${ }^{(11)}$. Overload, time limits and understaffing hinder collective and coordinated work.

On the other hand, as an evidence of the dynamism and complexity of the work and revealing the dialectical factor, the participants reported that, despite the division of labor, there is evidence of coordination between agents, knowledge and actions, which facilitates the relationship between agents, the teamwork and the attainment of the purpose of the work process. There is a routine based on the division of tasks but, on the other hand, agents try to develop work based on partnership, exchange and collaboration.

Thus, in spite of the barriers to the implementation of collective and coordinated work ${ }^{(12)}$, this modality may favor the reconstruction of relationships and contribute to the creation of a workforce focused on quality and comprehensive $\operatorname{car}^{(13)}$.

From this perspective, regarding Non-material work instruments, the interviewees showed that, when interpersonal relationships are based on communication, collaboration, cooperation, unity, respect and mutual help, the interactions facilitate teamwork in the Adult ICU. In addition, professionals associate these aspects with the achievement of the purpose of the work process, meaning that the proper use of non-material instruments contributes to better quality care. The topic of collaborative work is described in the speeches as a powerful tool for teamwork and comprehensive care.

In this sense, interprofessional actions, such as communication and coordination of knowledge, pointed out in some speeches, stimulate teamwork and cooperation between co-workers in the provision of care $^{(11)}$.
It is worth noting that effective communication between professionals in the workplace, friendly and relaxed relationships ${ }^{(11)}$, sharing of information and values and understanding of the attributions of the other professionals, unlike hierarchization, are essential for the integration between these professionals and for the quality of work ${ }^{(14-15)}$. Thus, interaction between team agents influences their behavior ${ }^{(16)}$.

Effective communication is one of the important pillars for teamwork, and ineffective communication can lead to unsafe care and inadequate care ${ }^{(17)}$.

Another aspect that was cited in the interviews as a facilitator for teamwork is knowledge, which was exemplified by professional training and education activities. This is a crucial point to elucidate that teamwork must be learned like so many other topics. In addition, knowledge must be valued to prepare the agent to act within the perspective of collective and coordinated work.

Educational interventions can be opportunities to improve assistance and delivery of care ${ }^{(11,18)}$, as acknowledged by the interviewees in their statements.

From this perspective, teamwork is still characterized as a challenge. Therefore, it is extremely important to review the concepts of learning and the ability to promote coordinated actions with all agents, favoring teamwork ${ }^{(19)}$. It is worth noting that collaboration also has an effect on learning, as it enables sharing of information, increasing of knowledge and generating new behaviors among professionals ${ }^{(20-21)}$.

On the other hand, revealing the dialectic and dynamic aspect of health work, respondents also reported that work in the Adult ICU is still based in individualism, fragmentation, little collaboration and inappropriate communication. This undermines teamwork and, consequently, the purpose of the work process, that is, the assistance provided. Another aspect pointed out in the statements is that professional category is something that generates inequalities and disadvantages in the daily work.

The fragmentation of health care is based on the specific practices of each professional area, related to the process of university education, which may influence the division of tasks and transfer responsibility from non-medical professionals to physicians, strengthening the model centered on the figure of the physician and stimulating hierarchization and lack of communication ${ }^{(22)}$.

The technical division of labor by specific attributions interferes in teamwork, increasing the distance between different areas, generating conflicts in the relationships between agents and fragmenting actions ${ }^{(23)}$.

Still regarding the instruments of the work process, now in relation to the material instruments, the statements demonstrated that the lack of material impairs the provision of care and causes conflicts between agents, undermining teamwork. Insufficient material resources can have a negative impact on the relationship between professionals, as the lack of this element can generate confusion and quarrels in the relationships.

The lack of material can affect quality of life at work, leading to lower job satisfaction, undermining workers' health ${ }^{(24)}$, hindering the integration of agents and impairing care.

Based on the results, it is essential to highlight that the work process in this Adult ICU, in relation to teamwork, is focused on non-material instruments of work, which reveals the importance of relational aspects. 
The initial intention was to have discussion groups with the agents of the Adult ICU after the conclusion of the research, to open up a debate and provoke reflection on the theme based on the findings of the study. However, this did not occur as the professionals could not leave the sector to participate in the activity, due to understaffing. Therefore, the results were presented to the professionals in the sector through a folder with guidelines on teamwork, a banner with the research results, and a presentation and discussion of the results in the three work shifts.

\section{Limitations of the Study}

The limitations of this study are related to its performance in a single ICU. However, even though this is a limitation, the results are not intended to be generalized. In addition, it is believed that the daily life and the work dynamics found in the scenario studied are similar to several other health services.

\section{Contributions to the Area}

It is noteworthy that professional education and training have emerged in the results as powerful tools to promote teamwork, which is not commonly evidenced in research. It is pertinent to highlight that the training and preparation of the professional for collective work should occur in courses other than nursing and that the service is also responsible for the professional qualification. The results are expected to stimulate the management of services to develop strategies to mobilize agents and provide training and appropriate conditions for teamwork.

\section{FINAL CONSIDERATIONS}

Using thematic analysis, this study allowed investigating the perceptions of health professionals regarding teamwork in the adult ICU, from the perspective of agents of the health team.

The results showed that, on the one hand, professionals perceive the existence of division and fragmentation of work. However, on the other hand, they also found incipient coordination between agents and their actions, which promotes teamwork and helps achieving the purpose of the work process. There are attempts to build collaborative working relationships, which demonstrated the dynamic and complex character of health services.

Aspects revealed as facilitating factors for teamwork include into interpersonal relationships based on communication and collaboration, integrated and collective work, adequate knowledge and training, and a reduced number of patients in the sector.

Some aspects were pointed out as hindering factors for teamwork: fragmentation by professional category; rigidity in the work routine; work overload, due to understaffing; and lack of time for discussion of clinical cases and meetings. The work developed in an individualistic perspective, with little or no collaboration/ communication, and lack of material impairs teamwork and compromises assistance.

We emphasize the need to revise the curriculum of health courses, with a view to including, implementing and/or improving discussions on the theme of teamwork in order to train professionals for a more integrated and perhaps even sympathetic health practice.

\section{REFERENCES}

1. Goulart BF, Camelo SHH, Simões ALA, Chaves LDP. Teamwork in a Coronary Care Unit: facilitating and hindering aspects. Rev Esc Enferm USP. 2016;5(3):479-86. doi: http://dx.doi.org/10.1590/S0080-623420160000400015

2. Silva SEM, Moreira MCN. Health team: negotiations and limits of autonomy, belonging and the acknowledgement of others. Ciênc Saúde Coletiva. 2015;20(10):3033-42. doi: 10.1590/1413-812320152010.20622014

3. Littike $D$, Sodré F. The art of improvisation: the working process of administrators at a Federal University Hospital. Ciênc Saúde Coletiva. 2015;20(10):3051-62. doi: 10.1590/1413-812320152010.00042015

4. Souza gc, Peduzzi m, Silva jam, Carvalho bg. Teamwork in nursing: restricted to nursing professionals or an interprofessional collaboration? Rev Esc Enferm USP. 2016;50(4):642-9. doi: 10.1590/S0080-623420160000500015

5. Peduzzi m, Norman IJ, Germani ACCG, Silva JAM, Souza GC. Interprofessional education: training for healthcare professionals for teamwork focusing on users. Rev Esc Enferm USP. 2013; 47(4):973-9. doi: 10.1590/S0080-623420130000400029.

6. Amaral EMS, Contim D, Vieira DS, Chavaglia SRR, OhI RIB. Perceptions about the work of the nursing team in adult emergency hospital service. REME Rev Min Enferm. 2017;21:e1023. doi: 10.5935/1415-2762.20170033.

7. Minayo MC. O desafio do conhecimento: pesquisa qualitativa em saúde. 13th ed. São Paulo: Hucitec; 2013.

8. Gonçalves RBM. Práticas de saúde: processos de trabalho e necessidades. São Paulo: CEFOR; 1992.

9. Alexanian JA, Kitto S, Rak KJ, Reeves S. Beyond the team: understanding interprofessional work in two North American ICUs. Crit Care Med. 2015;43(9):1880-6. doi: 10.1097/CCM.0000000000001136.

10. Manias E. The concept of teamwork does not fully explain how interprofessional work occurs in intensive care. Aust Crit Care. 2015;28(4):235-7. doi: 10.1016/j.aucc.2015.07.002

11. Santos LG, Lima MADS, Pestana AL, Colomé ICS, Erdmanna AL. Strategies used by nurses to promote teamwork in an emergency room. Rev Gaúcha Enferm. 2016;37(1):e50178. doi: 10.1590/1983- 1447.2016.01.50178

12. Adolpho CVT, Dias IMAV, Aveiro MC, Vasconcelos ACF. User perception on the approach of a team of multidisciplinary residents. Saúde Debate. 2015;40(107):1117-26. doi: 10.1590/0103-110420161070517 
13. Santos RMM, Chiari BM, Guedes ZCF. Facial paralysis and quality of life: a critical review of literature in the scope of interprofessional work. Rev CEFAC. 2016; 18(5):1230-7. doi: 10.1590/1982-0216201618519615.

14. Valentine MA, Nembhard IM, Edmondson AC. Measuring teamwork in health care settings: a review of survey instruments. Medical Care. 53(4):16-30. doi: 10.1097/MLR.0b013e31827feef6

15. Tubbesing G, Chen FM. Insights from exemplar practices on achieving organizational structures in primary care. J Am Board Farm Med. 2015;28(2):190-4. doi: 10.3122/jabfm.2015.02.140114

16. Pype $P$, Mertens F, Helewaut F, Krystallidou D. Healthcare teams as complex adaptive systems: understanding team behavior through team members' perception of interpersonal interaction. BMC Health Serv Res. 2018; 18:570. doi: 10.1186/s12913-018-3392-3.

17. Nogueira JWS, Rodrigues MCS. Comunicação efetiva no trabalho em equipe em saúde: desafio para a segurança do paciente. Cogitare Enferm. 2015;20(3):636-40. doi: 10.5380/ce.v20i3.40016

18. Oliveira FT, Stipp MAC, Silva LD, Frederico M, Duarte SCM. Behavior of the multidisciplinary team about Bundle of Central Venous Catheter in Intensive Care. Esc Anna Nery Rev Enferm. 2016;20(1):55-62. doi: 10.5935/1414-8145.20160

19. Jacowski M, Budal AMB, Lemos DS, Ditterich RG, Buffon MCM, Mazza VA. Teamwork: the professionals' perception of family health strategy. Rev Baiana Enferm. 2016;30(2):1-9. doi: 10.18471/rbe.v30i2.15145

20. Lingard L, Sue-Chue-Lam C, Tait GR, Bates J, Shadd J, Schulz V, et al. Pulling together and pulling apart: influences of convergence and divergence on distributed healthcare teams. Adv Health Sci Educ Theory Pract. 2017;22(5):1085-99. doi: 10.1007/s10459-016-9741-2

21. Tait GR, Bates J, LaDonna KA, Schulz VN, Strachan PH, McDougall A, et al. Adaptive practices in heart failure care teams: implications for patient-centered care in the context of complexity. J Multidiscip Healthc. 2015;19(8):365-76. doi: 10.2147/JMDH.S85817

22. Arruda LS, Moreira COF. Interprofessional collaboration: a case study regarding the professionals of the Care Center for Elderly, Rio de Janeiro State University (NAI/UERJ), Brazil. Interface Comun Saúde Educ. 2018;22(64):199-210. doi: 10.1590/1807-57622016.0613

23. Roloff DIT, Cezar-Vaz MR, Bonow CA, Lautert L, Sant'Anna CF, Couto AM. Occupational health nurses: interdisciplinary experience in occupational health. Rev Bras Enferm. 2016;69(5):897-905. doi: 10.1590/0034-7167-2015-0113

24. Tambasco LP, Silva HS, Pinheiro KMK, Gutierrez BAO. Satisfaction in the work of the multidisciplinary team which operates in Primary Health Care. Saúde Debate. 2017;41:140-51. doi: 10.1590/0103-11042017S212 